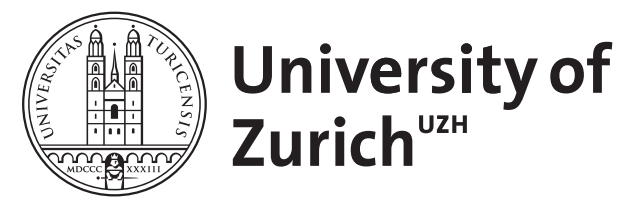

\title{
Chronographical Analysis: an Essay in Methodology
}

\author{
Steineck, Raji C
}

\begin{abstract}
In this essay I discuss the various ways time can be inscribed in texts below the level of explicit propositions about time. I argue that a full chronographical analysis needs to account for the dimensions of the theoretical, the practical, and the aesthetic. Taking Kant's table of categories as a guide to the fundamental functions of chronographic determination, I propose a methodology of analysis that goes beyond the aspect of quantitative measurement, and includes typological, thetic, and modal information about time. Numerous examples from various textual domains such as poetry, historiography, science, and law illustrate the wide applicability of the proposed analytical categories. The full matrix of dimensions and determinative functions can be used to describe the chronographic signature of a text, which depends as much on its communicative purpose as on the technologies of calculating and describing time available to its authors.
\end{abstract}

DOI: https://doi.org/10.1163/15685241-12341415

Posted at the Zurich Open Repository and Archive, University of Zurich

ZORA URL: https://doi.org/10.5167/uzh-158204

Journal Article

Accepted Version

Originally published at:

Steineck, Raji C (2018). Chronographical Analysis: an Essay in Methodology. KronoScope, 18(2):171198.

DOI: https://doi.org/10.1163/15685241-12341415 


\title{
Chronographical analysis. An Essay in Methodology
}

\section{Raji C. Steineck ${ }^{1}$}

published as:

Steineck, Raji C. 2018. "Chronographical Analysis: an Essay in Methodology”.

KronoScope 18 (September): 171-98. https://doi.org/10.1163/15685241-12341415.

For quotations, please use the published version.

\begin{abstract}
In this essay I discuss the various ways time can be inscribed in texts below the level of explicit propositions about time. I argue that a full chronographical analysis needs to account for the dimensions of the theoretical, the practical, and the aesthetic. Taking Kant's table of categories as a guide to the fundamental functions of chronographic determination, I propose a methodology of analysis that goes beyond the aspect of quantitative measurement, and includes typological, thetic, and modal information about time. Numerous examples from various textual domains such as poetry, historiography, science, and law illustrate the wide applicability of the proposed analytical categories. The full matrix of dimensions and determinative functions can be used to describe the chronographic signature of a text, which depends as much on its communicative purpose as on the technologies of calculating and describing time available to its authors.
\end{abstract}

1 Research for this paper was supported by an ERC Advanced Grant (No. 741166 - TIMEJ). The author wishes to thank the European Research Council for their generous support and all members of the TIMEJ group for their comments and suggestions on earlier versions of the manuscript: Dr. Simone Mueller, Dr. Kohei Kataoka, Dr. Daniela Tan, Dr. Georg Blind, Vroni Ammann M.A., Alexandra Ciorciaro M.A., Etienne Staehelin M.A. 


\section{Keywords}

time; chronography; chronometry; categories; schedules; aesthetics; literature

\section{Why chronography?}

How is time written into texts? This is the fundamental question of chronographical analysis. The basic assumption behind this question is that texts can reveal much more about the understanding of time than what they say by way of explicit propositions about it. ${ }^{2}$ A text may be completely devoid of such propositions, and still vividly embody a characteristic temporal outlook. If we want to fully grasp the understanding of time embodied in a given source, we need to account for all its ways of expressing its multifarious aspects, from the cognitive to the social and emotional. In order to do so, we need analytical categories that allow us to discern the relevant characteristics, and to identify their implications for the temporal outlook relevant to a text both on the operative and on the thematic level. In the following, I want to propose a system of such categories, and illustrate its application. I use a systematic approach, instead of an inductive one that would start from a certain corpus of texts, because I believe this is helpful to move beyond given assumptions about what constitutes chronography. I am motivated in this by the example of Roland Harweg's voluminous work on chronography in world literature, impressive in both its degree of elaboration, and in its failure to grasp fundamental chronographical dimensions: Harweg develops a fine-grained taxonomy with a total of seven levels and 52 subcategories $^{3}$, but he identifies chronography tout court with chronometric description - the description of time's quantitative dimension. Chronometric information is certainly important, and may indeed take precedence in many cultural domains, where we want to know when something happened, how long an event

\footnotetext{
2 Zanetti, Zeitoffen, 15.

3 Harweg, Zeit in Mythos und Geschichte, 3-5.
} 
lasted, or how often a certain action was repeated. But, as I hope to demonstrate in the following, it is not the only information about time to be expressed; and there are domains, such as poetry, where the aesthetic dimension is dominant and the typological function may assume comparatively more weight than the metric. Indeed, it may be helpful to characterize the chronographic signature of a given text (and possibly, genre or even cultural domain) through the full matrix of chronographic dimensions and functions it employs - a weighted matrix of the temporal features expressed in it (or absent from it), and the modalities of expression employed to that end.

There are several ways to think about a systematic approach to chronography; one could, for example, follow Gerard Genette's approach in his studies of narratology and simply use the various grammatical forms of verbal expressions as a guide. ${ }^{4}$ In this essay, I use Kant's philosophical taxonomy and his tables of categories and forms of judgment as a heuristic guide. ${ }^{5}$ The reason why I turn to this system is that time is not only integral to action, but also assumes the characteristics of an object that we try to apprehend, understand, and manipulate; as such, it may be better grasped through a categorical system that explores the totality of human ways to make sense of and in the world. Tables 1 and 2 give an overview of the dimensions of chronography and the functions of determination that follow from this choice of heuristics. All elements will be explained in the ensuing paragraphs (in parentheses).

\begin{tabular}{|l|l|l|l|}
\hline \multicolumn{4}{|c|}{ Table 1: Chronographic dimensions } \\
\hline dimension & Theoretical $(\S 3)$ & Practical $(\S 4)$ & Aesthetic $(\S 5)$ \\
\hline mode & descriptive & prescriptive & emotive \\
\hline $\begin{array}{l}\text { objective of } \\
\text { determination }\end{array}$ & what / how is time? & $\begin{array}{l}\text { what to do with } \\
\text { time? }\end{array}$ & how does time feel? \\
\hline
\end{tabular}

4 Genette, Figures III.

5 Kant, Kritik der reinen Vernunft, B 95-109. Cf. Kant, KrV, 147-59. 


\begin{tabular}{|c|c|c|c|c|}
\hline \multicolumn{5}{|c|}{ Table 2: Functions of determination } \\
\hline class & $\begin{array}{l}\text { metric } \\
(\$ \S 3.1,4,5)\end{array}$ & $\begin{array}{l}\text { thetic } \\
(\$ \S 3.2,4,5)\end{array}$ & $\begin{array}{l}\text { typological } \\
(\$ \S 3.3,4,5)\end{array}$ & $\begin{array}{l}\text { modal } \\
(\$ \S 3.4,4,5)\end{array}$ \\
\hline $\begin{array}{l}\text { categorial } \\
\text { group in Kant }\end{array}$ & quantity & quality & relation & modality \\
\hline $\begin{array}{l}\text { specified } \\
\text { determination }\end{array}$ & $\begin{array}{ll}\text { - } & \text { local } \\
\text { - } & \text { durational } \\
\text { - } & \text { iterative } \\
\text { - } & \text { limitative } \\
\text { - } & \text { consecutional }\end{array}$ & $\begin{array}{ll}\text { - } & \text { affirmative } \\
\text { - } & \text { negative } \\
\text { infimitative / } \\
\text { infinite }\end{array}$ & $\begin{array}{l}\text { - } \text { attributive } \\
\text { - causal } \\
\text { - implicative }\end{array}$ & $\begin{array}{l}\text { - hypothetical } \\
\text { - } / \text { problematic } \\
\text { - assertive } \\
\text { apodictic }\end{array}$ \\
\hline
\end{tabular}

I ask readers to understand that my intention here is neither to build a closed and complete system, nor to promote the Kantian system of philosophy over and against others. ${ }^{6}$ Instead, my aim is to establish the basic dimensions and functions of chronography, and to indicate the way to a well differentiated analysis that is applicable, and doing justice to, a wide variety of texts. I hope that others may build on my proposition or promote corrections and alternatives, as I try to integrate what has already been achieved in the field of chronographic analysis. My choice of examples is unavoidably eclectic. It is heavily influenced by my training as a Japanologist and, beyond that, admittedly witness to my educational history and personal predilections. I have attempted, however, to cover a certain range of different fields and symbolic forms. I hope readers will find the selection broad enough to illustrate the wide range of applicability and usefulness of the chronographic categories proposed here, beyond the boundaries of disciplines and cultural traditions.

\section{Dimensions of chronography}

6 It is even fairly safe to say that the application of Kant's table of functions of judgment to the subject of time runs counter to his own conception of time as a simple form of intuition. 
A first cue that we can take from Kant's system of philosophy is that there are three fundamental dimensions to chronography: a), the theoretical, b), the practical, and c), the aesthetic. In other words, the chronographic elements of a text may a), describe time, or b), prescribe temporal features, typically of an action or institution, or they may c), express how a person is affected by time and what, in turn, his or her attitude towards time is.

It should be noted that these fundamental dimensions are complementary, and not mutually exclusive in the sense that the presence of one excludes the presence of another. To the contrary, it is hard to conceive of a temporal prescription that does not contain descriptive elements, and more often than not, it will also give evidence of a certain attitude towards time. And while time can simply be described without prescriptive intent, there will usually be some expressive element to such description, pointing to an attitude towards time, or the way someone is affected by it. Moreover, many elements of descriptive chronography, and especially those pertaining to chronometry, were initially developed as part of prescriptive contexts, in order to determine the right time when something should be done (eg. ritual and agricultural calendars). ${ }^{7}$ Still, it seems reasonable to distinguish between descriptive and prescriptive chronography, not least because prescriptive chronography has its own specific genres, such as schedules and timetables. ${ }^{8}$

\section{Theoretical Chronography: Describing time}

7 This relation between chronometry and social organisation has been especially emphasized by Günter Dux, see his Die Zeit in der Geschichte: Ihre Entwicklungslogik vom Mythos zur Weltzeit: Mit kulturvergleichenden Untersuchungen in Brasilien (J. Mensing), Indien (G. Dux/K. Kälbe/J. Messmer) und Deutschland (B. Kiesel).

8 Zerubavel, "Timetables and Scheduling"; Zerubavel, Hidden Rhythms. 
Even if the need to co-ordinate social action, and thus to prescribe time, may be the dynamic source from which the larger part of metric chronography originates, their logical relation is arguably inverse: one can only prescribe a time that is known, and aptly described. For this reason, I will start here with the theoretical dimension of chronography, taking Kant's table of categories as a guide. ${ }^{9}$ Kant defines four groups of categories, each belonging to a specific determinative function: the quantitative, the qualitative, the relational, and the modal.

\subsection{Chronometry: quantitative determination}

Of these, the quantitative, or chronometric dimension, has received most attention so far. Kant's quantitative categories, unity, plurality, and totality, already point to two seminal chronometric functions: those of counting and measuring time; to these, Harweg in his elaborate chronometric typology adds the functions of locating events and processes in time, and of delimiting them. To this, I propose to add, taking my cue from Genette, the function of ordering in sequence. Harweg subsumes it under that of localization, but I think it deserves to be listed separately because of its importance in narrative and description - there is a difference in informational content between saying that apple trees in England blossom in May and may be harvested between July and November, according to the cultivar, or that apple trees first blossom in spring and then bear fruit in summer. The sequence may be inferred from the first sentence, but is only explicitly established as a temporal rule in the second. ${ }^{10}$

Harweg provides further useful distinctions concerning the mode of quantitative determination, which may be either implicit or explicit; and when explicit, material or formal; when formal, denominative or numeralized. He synthesizes the taxonomy of subcategories created through these distinctions under two general headings: a)

9 Cf. Kant, Kritik der reinen Vernunft (herafter: KrV), B 95, 106; Kant, KrV, $148,156$.

10 Cf. "Apple", Wikipedia, accessed Feb. 27, 2018, https://en.wikipedia.org/wiki/Apple. 
chronometries that permit to establish a distinct temporal relation between the event or process described and the reader's present, which he aptly characterizes as "historiographic"; and b) those that do not establish such a relation, which he (less aptly, I believe) terms "mythographic". In less loaded terms, this amounts to distinguishing between fully relational chronography, which establishes temporal localization with respect to the present (and thereby, potentially, to the totality of events), and a chronography that is absolute, in the sense of remaining removed from such relation. Contrary to the evolutionary hierarchy implied in the terms "mythographic" and "historiographic", it should be noted that in many contexts, absolute chronography is actually to be preferred, and not detrimental to the exactness required: when establishing, for example, the temporal relation between the lunar cycle and the solar year ( 1 solar year $=12.368777514$ lunar months), it is useful and appropriate to record that relation without dating it; and the same holds for the formulas of physics, botanical information, cooking recipes and so forth. It is thus important to take note that quantitative chronography does neither start nor necessarily end with formal attribution of dates that allow temporal location in relation to the totality of events; it can take on many different shapes, depending not only on the chronometric means available, but also on the ends of the specific kind of communication. To illustrate that variety, and also the meaning and usefulness of the distinctions mentioned above, let us briefly look at a couple of examples. The second song of Robert Schumann's Dichterliebe after poems by Heinrich Heine starts with two lines exhibiting implicit material chronography:

"Aus meinen Tränen sprießen / viel blühende Blumen hervor ..." ("Out of my tears of yearning the blossoming flowers throng" 12 ), with "sprießen / throng" indicating a beginning, and "blühende Blumen/ blossoming flowers," subsequent duration, thus also establishing a measure and a sequence. Implicit chronometric information is especially rich in languages with an elaborate system of aspect in verb forms, such as classical Japanese or Polish and Russian.

11 Heine, "Buch der Lieder-Lyrisches Intermezzo," 60.

12 Heine and Draper, "Book of Songs-Lyrical Intermezzo," 52. 
The first song of Dichterliebe, in contrast, starts with a line that uses formal denominative chronography ("Im wunderschönen Monat Mai / In May, the magic month of May" ${ }^{\prime 13}$ ), complemented by a second line employing explicit material chronography ("Als alle Knospen sprangen / When all the buds were springing" ${ }^{14}$ ), both to locate the event central to the poem: "Da ist in meinem Herzen die Liebe aufgegangen / Into my heart the burning bright arrow of love came winging." 15 ) The second and third line are explicit-material, because they may be used to answer the question "when" without using the names or numbers of temporal units.

Compare this to the following poem by Emily Dickinson, which counts, localizes and delimits primarily by use of formal, denominative chronography, supported by implicit material temporal expressions:

Summer has two Beginnings -

Beginning once in June -

Beginning in October

Affectively again -

Without perhaps the Riot

But graphicker for Grace -

As finer is a going

than a remaining Face

Departing then - forever -

Forever - until May -

Forever is deciduous -

Except to those who die. ${ }^{16}$

The final verse draws its force from a series of contrasts: a formal, denominative localizing delimitation (“[departing] until May") is combined with a formal predicate

13 Heine, 60; Heine and Draper, 52.

14 Heine, 60; Heine and Draper, 52.

15 Heine, 60; Heine and Draper, 52.

16 Dickinson, Poems, 149. 
("forever") that denies such delimitation by indicating infinite measure. This is, in turn, contrasted with the material predicate "deciduous" which implies intermittent (and thus, durationally delimited) iteration. Again, this is set in opposition to "those who die", containing implicit information about a final temporal limitation, which indicates that they will not live to see such iteration.

The supportive, accentuating force of implicit chronography is similarly visible in the following lines by the leading Japanese court poet of the late $7^{\text {th }}$ century, Kakinomoto no Hitomaro ${ }^{17}$, and a parody (albeit a serious one) composed half a millennium later by the Zen master Dōgen (1200-1253) ${ }^{18}$ :

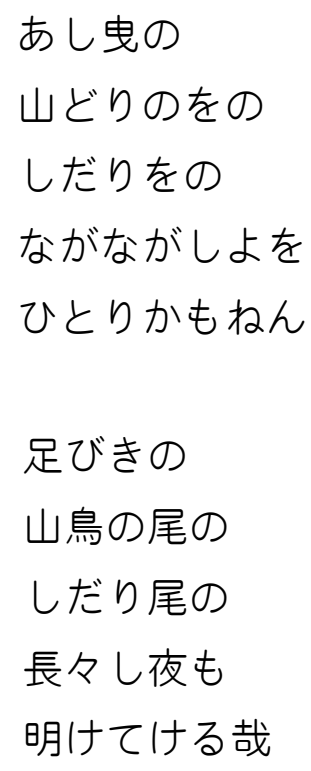

Ashibiki no

yamadori no

shidario no

naganagashi yo o

hitori kamo nen

Ashibiki no
yamadori no o
shidario no

naganagashi yo mo

aketekeru ya
The foot-draggingmountain pheasant'sdangling tail long, long night am I to spend alone?

The foot-draggingmountain-pheasant'sdangling-taillong, long night as well has lifted and gone for good.

The dubitative, open ended aspect (expressed in the auxiliary verb - $m u$ ) of the final line in Hitomaro's poem is exchanged by Dōgen with a completive aspect (marked by

17 Shinpen Kokka Taikan Henshū Iinkai, Shinpen kokka taikan, 5:933. See Honda, One Hundred Poems from One Hundred Poets, 3. for the Japanese text and an alternative translation of Hitomaro.

18 Ōkubo, Dōgen Zenji Zenshū, 2:413. See Heine, The Zen Poetry of Dōgen: Verses from the Mountain of Eternal Peace, 108. for an alternative translation of Dōgen. 
the combination of the auxiliary verbs -te and -keri) pointing to the achievement of enlightenment: what was, in the original, a long night of solitude and separation expected by a lonely lover has become a thing of recollection, the long night of delusion, which has finally given way to the light of wisdom.

It is fairly obvious that all examples given so far belong to the domain of absolute chronography; but what about a poem centering around a formal date, such as Machi Tawara's "Salad Memorial Day"?

「この味がいいね」と君が言ったから七月六日はサラダ記念日 ${ }^{19}$ ("Since you said / 'This tastes really good' / July 6 is / Salad memorial day")

In spite of the fixed location of this new memorial day (which we would have no trouble finding in our calendars), the chronography remains absolute because there is no way of knowing when exactly the said tradition was established. There are, however, rich implications, because July 7 (or, more precisely the $7^{\text {th }}$ day of the $7^{\text {th }}$ month) coincides with the Tanabata festival, which commemorates a heavenly couple that is allowed to see each other only once per year from afar - pointing to the fact that different times not only have their locations and measures, but also specific characteristics, which are determined by way of chronotypological relational categories (see below, section 3.3).

It would seem that such is the way of poetry, and, one might add, fictional prose; but that is not the case. Compare the first lines of Nakano Shigeharu's (1902-1979) poem on the $10^{\text {th }}$ anniversary of the Soviet Revolution ${ }^{20}$ :

壁新聞をつくるソ同盟の兄弟

一九二七年十一月

君らは十月の暦をめくつた指できりぬき

\section{Our Soviet brothers, making wall newspapers}

November 1927

You, cutting with fingers that have leafed through the pages of October

19 Tawara, Sarada kinenbi, $12 \%$.

20 Nakano, Nakano Shigeharu shishū, 51. 
かつて血にぬれた手で挟み切る

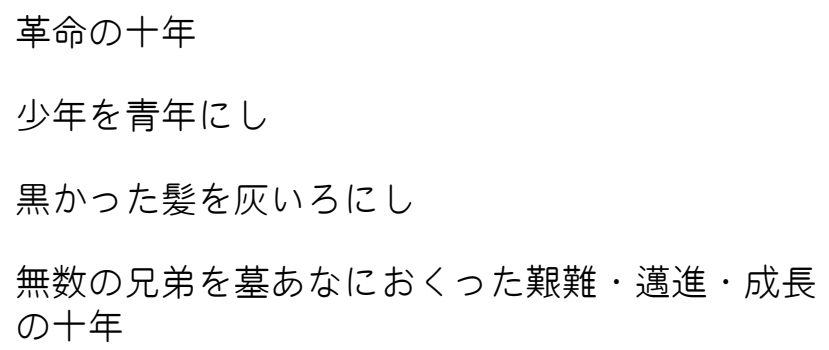

As is evident from the poem's use of tense, the date in the first line indicates the poem's presence. Any competent reader can thus determine the distance of the time of the poem to his or her own time. This makes the poem's chronography fully relational (or, in Harweg's terms, "historiographic"). The features that achieve this deserve further attention. In the Japanese version, the first line consists entirely of numbers combined with temporal units ("month 11, year 1927"). They indicate the location in an open-ended, global numerical system of time reckoning that we may call, for the sake of these characteristics, fully chronoarithmetic. That alone, however, would leave readers in the dark about the actual temporal position of the poem, which is here provided implicitly by the usage of the tenses (past tense and present). A deictic expression, such as "Today, in November 1927" might have fulfilled the same function.

To generalize, fully relational metric chronography requires the combination of two elements: "stereometric" temporal information that allows to calculate the temporal distance between any two events, and "kathizometric" (from $\alpha_{0} \theta \zeta_{\zeta} \omega=$ seat, position) information as conveyed by positional temporal markers such as tenses or auto-deictic expressions (now, today, this week). It deserves mentioning, however, that the simple recording and placement of a numerical date, eg. on top of a letter or in the header of 
a newspaper, may serve both functions, even if the kathizometric information is only implicit and has to be inferred from one's knowledge of genre conventions. ${ }^{21}$ In terms of contemporary Anglo-American philosophy of time, this means that fully relational metric chronography is determined in both the A-series and the B-series of time. ${ }^{22}$ Both functions (the stereometric and the kathizometric) can be fulfilled, as we have seen, by way of implict and explicit, material and formal chronography. This distinction thus does not conform to the taxonomy provided by Harweg; it is, however, seminal for the chronographic signature of a text: does it foreground, as kathizometric chronography does, the position of events and processes in relation to relevant instances of communication, be they the writer and her / his readers, or the protagonists of an action recounted? Or do stereometric relations command more attention, which is often the case when regularities are being described? The degree of exactness in demand in both respects can vary greatly according to the communicative function of a text; and fully relational metric chronography is, on the whole, the exception rather than the rule. Even if available, it may often seem unnecessarily cumbersome, and be replaced with appropriately abbreviated notation; or it would, as in the case of natural laws, impose an apparent restriction on the validity and applicability of the content that runs counter to the communicative intention: dating a natural law may be of interest in the history of science, or in the promotion of a scientist's career; but it is not essential (and even detrimental) to the scientific purpose itself; a formula, such as Newton's law of universal gravitation, will therefore normally be used without indexing it with a date.

21 I argue here that such implicit information should however count as part of the chronography of a document, in order to avoid the conclusion that a letter dated "March 1, 2018" is not fully relational in terms of chronometry, although its dating fulfils the legal function of making it so. See https://en.oxforddictionaries.com/writing-help/how-to-lay-out-a-letter\#date, accessed March $1,2018$.

22 This distinction goes back to a seminal paper by J. Ellis McTaggart ("The Unreality of Time."). The term A-series designates the kathizometric series of past, present, and future; the B-series, the stereometric series of before and after. 
On the other hand, as Harweg demonstrates, stereometric systems that allow to locate any event in a universal system of temporal coordinates are a late and rare development in human history. The Christian, or meanwhile, common era, as it has been adopted even by the avowedly atheist People's Republic of China, only achieved the ability to date events before the alleged birth of Christ through the adoption of the BCE reckoning in the late $17^{\text {th }}$ century; the system of Julian dates (JD), which is much more unwieldy for purposes of history and everyday life, because it does not make use of months and years, was developed by the $16^{\text {th }}$ century astronomer Joseph Justus Scaliger to accommodate for that fact. ${ }^{23}$

The East Asian system of Imperial Era names, still in use in Japan for dating national events and procedures, requires command of a chronological list of such eras. Furthermore, it is not designed for locating events in the more distant future: In principle the current era name (as of 2018) can be projected indefinetely into the future. But to speak of Heisei 162 in order to identify the year 2150 of the common era runs counter to the common sense expectation that, even granted the stability of Japan's political system, a different monarch, and therefore, a different era name will be in place at that time. As far as history was concerned however, earlier Japanese authors were already able to accommodate dates in the very distant past by attributing reigns of several hundred thousand years to heavenly sovereigns in the age of gods posited by official imperial historiography. Thus, the aristocratic historiographer Kitabatake Chikafusa (1293-1354 CE) located the birth of the Buddha in the 835,667 th year of the reign of the mythical sovereign Ugayafuki Aezu. ${ }^{24}$ He did not, however, subject this event to Japanese imperial chronology, but only noted a correspondence, because the range of application of the Japanese imperial calendar corresponds to the geographical reach of the empire. Since Japan, unlike China, has historically recognized the existence of other empires, it accepted that different calendars were valid in different domains; as Kitabake's example shows,

23 Harweg, Zeit in Mythos und Geschichte, 35-36.

24 Kitabatake et al., Jinnō shōtōki. Masukagami, 87:65; Kitabatake, A Chronicle of Gods and Sovereignns: Jinnō Shōtōki, 83. 
these calendars could be coordinated, but neither could claim universal validity. A similar method was used in Islamic historiography. The historiographer and polymath Al-Bīrūnī (973-1048 CE), for example, in his "Chronology of ancient nations" discusses the periodization of events prior to the Hijrah (Mohammed's relocation of his community to Medina in $622 \mathrm{CE}$ ) in reference to biblical accounts (the eras of creation and deluge, the era of Nebukadnezar), Greek (notably Alexander the Great) and Roman monarchs (Augustus and Diocletian), and presents comparative chronological tables representing various traditions. ${ }^{25}$

To briefly return to Japan, since the $19^{\text {th }}$ century common era dating has been quietly accepted for events outside Japan and for purposes of international communication. In fact, the common era is also widely used inside Japan for practical reasons (e. g. to locate events in the future or those belonging to more distant imperial eras). Sometimes, but by no means exclusively, common era dating is also employed to emphasize a decidedly democratic political stance - hinting at the aesthetic dimension of chronographic information to be discussed below in paragraph 5 .

\subsection{Chronothesis: affirming or negating time}

The header of Kant's second group of categories, quality, is somewhat misleading if we adhere to the common understanding of the term. It subsumes the functions of either affirming or negating whether a subject is joined to a predicate, or of stating that it belongs to a different realm of predicates altogether. A chronothetic proposition therefore either affirms or denies that something has certain temporal characteristics, or it determines whether it belongs to the realm of time, or not. For example, in Euclidic space, the factor $\pi$ is a constant that indicates the ratio between the circumference of a circle and its radius $(\mathrm{C}=2 \mathrm{r} \pi \rightarrow \mathrm{C} / 2 \mathrm{r}=\pi)$ independent of time. It is therefore often said that mathematical constants such as $\pi$ are a-temporal - a

25 Abu-'r-Raiḥān Muḥammad Ibn-Aḥmad al- Bīrūnī and Sachau, The Chronology of Ancient Nations, 16-33, 154-55.I am indebted to my colleague at University of Zurich, Ulrich Rudolph, for pointing me to this source. 
limitative chronothetic proposition that places mathematical relations outside of the realm of time.

In contrast, there is discussion whether the gravitational constant G in Newtonian equations may oscillate over time. A 2015 paper concludes with the following careful chronographic affirmation: "Apparently, there does seem to be a secular or very long period (greater than 20000 years) $G$ variation in the Solar System, but of order $10^{-6}$ smaller than the variation shown in fig. $1 .{ }^{26}$

More often than not, chronographic affirmation will however remain implicit. All chronometric expressions, for example, also serve the function to state that the objects, events, and processes in question are indeed subject to temporal determination. We immediately understand that the opening lines of Ovid's first tale of metamorphosis describe a temporal state of affairs, without needing an explicit statement to tell us so:

Ante mare et terras et, quod tegit omnia, caelum / unus erat toto naturae vultus in orbe $[\ldots]^{27}$ [Before there was sea, earth, and sky (which covers everything), the face of nature was the same throughout the universe. $\left.{ }^{28}\right]$.

Chronographic negation can be specific and deny that something was, is, or will be the case at a certain time. The Buddhist cleric and historiographer Jien (1144-1225) in his Gukanshō (c. 1220) imputes the following reasoning to the mythical emperor Ōnin, who was later identified with the deity/bodhisattva Hachiman, protector of Buddhism:

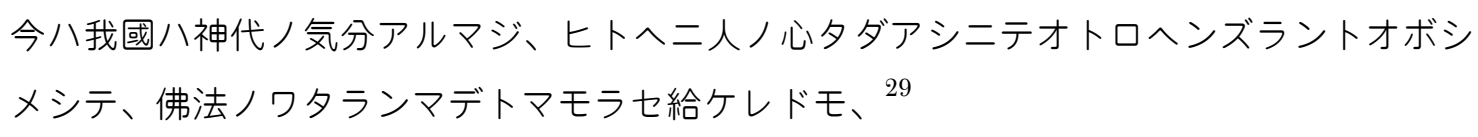

26 Anderson et al., "Measurements of Newton's Gravitational Constant and the Length of Day."

27 Publius Ovidius Naso and Albrecht, Metamorphosen, Nr. 1360:6.

28 Publius Ovidius, The Metamorphoses of Ovid, 9.

29 Okami, Gukanshō, 135 (Fasc. 3). 
Since our country is no longer to have the spirit of the age of Kami, and the situation is henceforth destined to deteriorate rapidly .... I will protect the country until the introduction of Buddhist law. ${ }^{30}$

But negation can also be general, denying a certain state or event a place in time altogether, as in Shakespeare, "The course of true love never did run smooth." ${ }^{31}$ Such general chronographic negation seems to need explicit expression, while specific negation may be implicit in the denial of an action or event. "Since I receiv'd command to do such business, I have not slept one wink" ${ }^{32}$, Shakespeare has Pisanio say, and that is enough to negate that there was a time when he was idle.

Is there also implicit limitative information? One might argue that strict avoidance of all temporal markers and indicators in description of an object would amount to as much. Such language is restricted to the description of attributes and states, avoiding all mention of action or change, or it reserves such mention for references to acts of cognition, as in the first statements of Spinoza's Ethica more geometrico:

I. Per causam sui intelligo id, cujus essentia involvit existentiam, sive id, cujus natura non potest concipi nisi existens.

II. Ea res dicitur in suo genere finita, quae alia ejusdem naturae terminari potest. Ex. gr. corpus dicitur finitum, quia aliud semper majus concipimus. Sic cogitatio alia cogitatione terminatur. At corpus non terminatur cogitatione nec cogitatio corpore. ${ }^{33}$

(I. By a thing which is its own cause, I understand a thing the essence of which involves existence, or the nature of which cannot be conceived except as existing.

30 Brown and Ishida, The Future and the Past: A Translation and Study of the Gukanshō, 25.

31 “A Midsummer Night's Dream", The Complete Works of William Shakespeare, 220.

32 Shakespeare, "Cymbeline", 1274.

33 Spinoza, Ethik in geometrischer Ordnung dargestellt, 45. 
II. What can be limited by something else of the same nature is called something that is finite as a kind. E. g. a body is called finite, because we can always conceive of a larger one. Similarly, a thought is limited by another thought. But a body is not limited by a thought, nor a thought by a body. ${ }^{34}$ )

As illustrated by this example, logic and mathematics are the proper genres of such atemporal parlance. Spinoza's reflection on the causa sui, however, also points to a positive meaning that may be contained in a limitative expression. A predicate such as "eternal", for example, seems to say something more than simply negating dependence on / variability over time: it hints at a realm that is both present in the temporal and removed from its limitations. Christian mystical thinkers, such as Eckhart (1260-1328), have attempted to formulate a rational theory of eternal existence:

[...] significanter non ait a principio, sed in principio deum creasse. ${ }^{35}$

(That is why the text aptly says that God created not from the beginning but in the beginning. ${ }^{36}$ )

[...] principium, in quo deus creavit caelum et terram, est primum nunc simplex aeternitatis, ipsum, inquam, idem nunc penitus, in quo deus est ab aeterno, in quo etiam est, fuit et erit aeternaliter personarum divinarum emanatio. [...] Non enim imaginandum est falso, quasi deus steterit exspectans nunc aliquod temporis futurum in quo crearet mundum. Simul enim et semel quo deus fuit, quo filium sibi coaeternum per omnia coaequalem deum genuit, etium mundum creavit. ${ }^{37}$

(The beginning, in which god created heaven and earth, is the simple first now of eternity, exactly the same now, I say, in which god is from eternity, in which

34 Spinoza, Ethics by Benedict de Spinoza, 2.

35 Eckhart, "Prol. Gen.," 162.

36 Eckhart, "Prol. to the Opus Tripartitum," 89.

37 Eckhart, "Exp. Gen.," 190. 
is, was, and will eternally be the emanation of the divine persons. [...] One should not wrongly imagine that god had stood waiting for a now of some future time in which he would then have created the world. Once and when god was, when he brought forth his co-eternal son, who is co-equal with god in everything, he also created the world. ${ }^{38}$ )

On a more light-hearted note, the Austrian writer Ernst Jandl in the seventh of a ten piece set of poems composed in both German and English quipped:

a hundred / two hundred / years ago / this / would have been written / in exactly the same way / "then I am timeless" / "no, dead"39

3.3 Chronotypology: temporal relations

The question, what time it is (or was, related to a given event), may be correctly answered in two fundamental ways. The first is to simply respond with chronometric information, as in the following exchange from Oscar Wilde's The Picture of Dorian Gray:

"What time is it?" "Ten minutes past two, sir," answered the man, blinking. ${ }^{40}$

The second way is to answer by chronotypological information, information characterizing time, for example, by linking it to action, such as in "Okay, people, it's time to rock and roll." ${ }^{41}$ In many instances, this even may be the more direct and appropriate answer, as it directly responds to the question's pragmatic motive. Formally speaking, in this case an implication is used to describe what time it is, corresponding to the third of Kant's categories of relation. In contrast, time is often characterized by way of attributes in more contemplative settings. To return to Ovid for an example:

38 I would like to point Anglophone readers to the translation Eckhart, "Expositio Libri Genesi.",82121, which, however, I was not able to consult.

39 Jandl, Selbstporträt des Schachspielers als trinkende Uhr, 37.

40 Oscar Wilde, 202.

41 Garber, Vertical Run, 234. 
Verque novum stabat cinctum florente corona, stabat nuda aetas et spicea serta gerebat, stabat et Autumnus calcatis sordidus uvis, et glacialis Hiems canos hirsuta capillos. $^{42}$

(... and the new Spring, wearing a crown of flowers; Summer stood there, too, naked except for a garland made from ears of grain; and Autumn was there, stained by the grapes he had trampled, and icy Winter, bristling with snowwhite hair. ${ }^{43}$ )

Chronotyplogies such as this one are often linked in the literature with archaic systems of knowledge. ${ }^{44}$ In fact, and for obvious reasons, agricultural civilizations have developed elaborate systems of chronotypological knowledge and description at a fairly early point in history. The classical Chinese system of correspondences, which found its classical formulation in the Han period (206 BC-220 AD), is a prominent example. ${ }^{45}$ However, since such typologies were developed for practical purposes, I will defer their discussion to the pertinent section of chronopraxis (Section 4). Suffice it to say here that its seniority has not made this kind of knowledge, or the concomitant chronography, obsolete. To the contrary, it continues to be important in fields such as chronobiology, economics, psychology as well as in descriptions of the personal experience of time. To return to a suspense novel already quoted above:

Here in the jungle there are two kinds of time-long time and slow time. Long time is what you usually get. You sit beneath a tree or in a hooch or in a field tent, or maybe you're tiptoeing Indian file through the boonies, and nothing happens. Hours pass, and nothing happens, Then you look at your Timex and discover that it has only been five minutes since the last time you looked at it.

42 Publius Ovidius Naso and Albrecht, Metamorphosen, Nr. 1360:64.

43 Publius Ovidius, The Metamorphoses of Ovid, 26.

44 Cassirer, Philosophie der symbolischen Formen II, 2: Das mythische Denken:129-34; Dux, Die Zeit in der Geschichte: Ihre Entwicklungslogik vom Mythos zur Weltzeit: Mit kulturvergleichenden Untersuchungen in Brasilien (J. Mensing), Indien (G. Dux/K. Kälbe/J. Messmer) und Deutschland (B. Kiesel), 123-25.

45 Unschuld, Medicine in China, 52-61. 
Long time.

The other kind of time is slow time. There's a flat metallic snap, the receiver of an AK-47 chambering a round. then there is fire and explosions and screams and the whine of bullets all around and each one aimed at you for unending eternity. [...] Slow time. The clock gets choked with molasses. Men weep at how slow the seconds pass. [...] They are the hardest of the hard, the baddest of the bad. Nothing fazes them. They look at their watches. They weep. ${ }^{46}$

One may argue that such statements are not properly about time; they are about the experience of time. That, however, is a philosophical discussion. What is recorded here are evidently and expressly statements about time, and these are the subject of chronographical analysis.

\subsection{Modality}

The final group of categories to be considered do not determine the content of what is said about time; instead, they convey information about the status of the thetic, metric, or typological statements made: are they meant to be assertions of facts, or hypothetical/problematic, i. e. assumptions about possibilities, or are they apodictic, that is, do they describe something as being necessarily true?

The first few pages of Sterne's Tristram Shandy contain exemplary cases of both temporal conjectures and assertions:

As my life and opinions are likely to make some noise in the world, and if I conjecture right, will take in all ranks, professions, and denominations of men whatever, -be no less read than the Pilgrim's Progress itself-and in the end, prove the very thing which Montaigne dreaded his Essays should turn out, that is, a book for a parlour-window;-I find it necessary to consult every one a little in his turn. ${ }^{47}$

46 Garber, Vertical Run, 14.

47 Swift and Sterne, Guliver's Travels. Tristram Shandy, 193. 
[...] On the fifth day of November, 1718, which to the era fixed on, was as near nine calendar months as any husband could in reason have expected,-was I Tristram Shandy, Gentleman, brought forth into this scurvy and disastrous world of ours. ${ }^{48}$

The very first chapter of that novel also demonstrates that hypothetical judgments are not tied with propositions about the future; for it starts out with pondering a counterfactual possibility:

I wish either my father or my mother, or indeed both of them, as they were in duty both equally bound to it, had minded what they were about when they begot me; had they duly considered how much depended upon what they were then doing;--that not only the production of a rational Being was concerned in it, but that possibly the happy formation and temperature of his body, perhaps his genius and the very cast of his mind;--and, four aught they knew to the contrary, even the fortunes of his whole house might take their turn from the humours and dispositions which were then uppermost;-Had they duly weighed and considered all this, and proceeded accordingly,-I am verily persuaded I should have made a quite different figure in the world, from that in which the reader is likely to see me. ${ }^{49}$

Conjecture about the past is, however, not limited to the pondering of counterfactual possibilities; in the absence of certain documentation, the hypothetical mode is indispensable to much of historiographical writing as well. Writing about a seminal debate concerning the perspectives for Buddhist enlightenment initiated by Kūkai (774-835), the founder of Esoteric Buddhism in Japan, Ryūichi Abé states:

[...] The Hossō priest Tokuitsu (781?-842?) provides a valuable insight to the initial reaction by the Buddhist scholarly establishment in his work Unresolved Issues on the Shingon School [...] On the fifth day of the fourth month of Kōnin

48 Swift and Sterne, 194.

49 Swift and Sterne, 191. 
$6(815)$, Kūkai sent his request to Tokuitsu, who was then residing at Aizu in the province of Mutsu. Although undated, Unresolved Issues was prepared by Takuitsu as his response to Kūkai's letter. It thus seems highly likely that it was also written in 815 or at most a few years later.

Abé could have added here to his factual and hypothetical statements a proposition in the remaining, apodictic mode, indicating a temporal necessity: Since Unresolved Issues is a response to Kūkai's request, it cannot predate it, and must have been written in 815 or later. As Kant pointed out, such apodictic propositions are tied to the imputed knowledge about logical or causal relations. This is also evidenced by the famous predictions contained in Marx's Capital:

The monopoly of capital becomes a fetter upon the mode of production, which has sprung up and flourished along with, and under it. Centralisation of the means of production and socialisation of labour at last reach a point where they become incompatible with their capitalist integument. This integument is burst asunder. The knell of capitalist private property sounds. The expropriators are expropriated.

The capitalist mode of appropriation, the result of the capitalist mode of production, produces capitalist private property. This is the first negation of individual private property, as founded on the labour of the proprietor. But capitalist production begets, with the inexorability of a law of Nature, its own negation. It is the negation of negation. This does not re-establish private property for the producer, but gives him individual property based on the acquisition of the capitalist era: i.e., on co-operation and the possession in common of the land and of the means of production. ${ }^{50}$

The validity of the statement is not in question here. In terms of chronographical analysis, suffice it to say that the apodictic statement about an event that is yet to come is written in a present tense. This both emphasizes the preemption of the future

50 Marx, "Chapter Thirty Two-Historical Tendency of Capitalist Accumulation," 837. 
and precludes definition of a precise temporal horizon. The seemingly atemporal mode of writing is in keeping with the scientific character the prognosis claims for itself - but it contradicts the fact that its object is a future historical event in need of chronometric localization. The unhappy juncture of unspecified prophesy and scientific parlance has haunted the Marxist tradition ever since, deflecting attention from what is arguably the center of Marx's analysis, that is the critique of capitalism and its ideological theoretization in political economy.

\section{Practical Chronography: Prescribing Time}

As I have mentioned already, a large part of descriptive chronography (and of its underlying technological and conceptual instruments) was actually developed for the practical purpose of coordinating and timing human activities. As Günter Dux has argued, command of fully relational abstract global time ("abstrakte Weltzeit") is a function of systemic social co-operation transcending the reach of the immediate individual umwelt, circumscribed by unassisted sensual perception and communicative action. Only when human beings live by participating in institutions that demand coordination beyond the immediate exchange of orders and appointments do they habitually start to think and communicate about time in terms of abstract, homogeneous metric units. ${ }^{51}$ The evidently religious and political denotations employed in the pertinent systems of time-reckoning bear witness to this social origin of chronometry. Furthermore, as Zerubavel has demonstrated, while some fundamental temporal units may appear purely descriptive, because they are based on natural rhythms such as the day, the month, and the year, others, like the week, are without such basis. ${ }^{52}$ They are inventions made for the sake of practical purposes in the coordination of human activities.

51 Dux, Die Zeit in der Geschichte: Ihre Entwicklungslogik vom Mythos zur Weltzeit, 80-100. See also Steineck, "Time in Old Japan."

52 Zerubavel, The Seven Day Circle. 
In principle, practical chronography employs the same functions as descriptive chronography to determine the time of the prescribed actions and events. However, the emphasis may differ, and there are specific formats of temporal prescription, such as schedules and timetables, that are of a genuinely practical orientation, even if they may be used, after the fact, to describe recurring actions and to contextualize individual events.

In terms of chronometry, it can be important to locate, measure, count, and delimit the appropriate time of an action or event. In principle, all these functions may be fulfilled by implicit material chronography, but there is an inherent tendency towards formal chronography if a prescription is put down in writing instead of being verbally communicated. The medium already suggests a distance, both spatial and temporal, between a situation $\mathrm{A}$ in which the prescription is given and a situation $\mathrm{B}$ when it is to be executed. It is thus not by chance that the famous initial dialogue from Macbeth ("When shall we three meet again / In thunder, in lightning or in rain?" / "When the hurlyburly's done, when the battle's lost and won." $)^{53}$ renders a conversation and not a written appointment.

Compare this to the (much older) order the Japanese monarch Jitō (645-703; r. 686 through 697) communicated to provincial governors; it is recorded in the Nihon shoki 日本書紀 ("Annals of Japan") as dating from the $10^{\text {th }}$ day of the $8^{\text {th }}$ intercalary month of the $3^{\text {rd }}$ year of her reign (appr. September 688 ):

今冬戸籍可造。宜限九月糺捉浮浪。 54 This winter, household registers are to be compiled. Therefore, vagrants are to be apprehended until the $9^{\text {th }}$ month.

Another order, dating from the first year of her reign, employs the system of year reckoning by location in the sexagenary cycle of 10 celestial stems and 12 terrestrial branches to establish a retroactive time limit for the calculation of interest:

凡負債者、自乙西年以前物、莫收利也。若既役身者、不得役利。 55

53 Shakespeare, The Complete Works of William Shakespeare, 1051.

54 Kojima, Nihon shoki 3, 498. 
Concerning persons carrying debts, it is prohibited to take interests for debts incurred before the yin wood-rooster year [685]. If repayment is made by labor, it will not do to have them work for the accumulated interest as well.

In a similar manner, the oldest extant Japanese legal code determines frequency and duration of the regular duties of the palace guard, down to the scale of the hour:

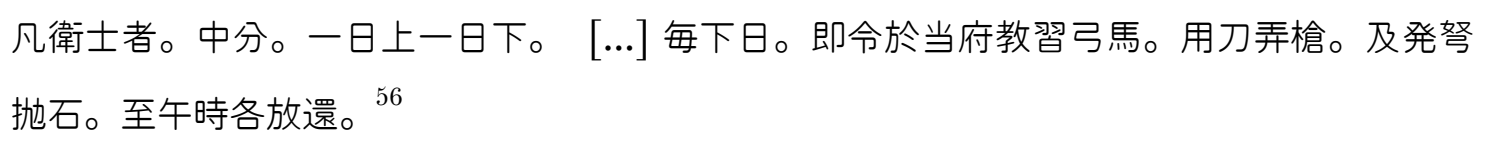

The palace guard shall be evenly parted. Each group is to serve one day at the palace and to be released the other day. [...] On that second day, they shall be at the garrison and train mounted archery, fencing, fighting with spears, and shooting the great crossbows and catapults. They are to be released when the hour of the horse [11a.m.-1p.m.] arrives.

As this example indicates, formal chronometry is especially pertinent to the scheduling of regularly recurring activities. It is therefore also employed in cultural contexts that are habitually associated with an emphasis on a qualitative approach to time. A 13th century codex of rules for Chan/Zen Buddhist monasteries exemplifies this tendency in determining the appropriate rhythm for formal and informal lectures by the master to his community; it demonstrates how, in the absence of the formal temporal unit of the week, events that were set to recur regularly several times a month were schedules according to the number of the calendar days:

五日挵堂激揚宗旨。三八念誦報答龍神。請益玄言發明今古。小參家訓網紀叢林。 ${ }^{57}$

55 Kojima, 480.

56 Inoue, Ritsuryō, 3:321.

57 Changlu Zongze, “Chanyuan Qinggui” Fasc. 2 上堂, chapter 小参 (Informal teaching) 
Every five days ${ }^{58}$ the abbot ascends the platform [i. e., gives a formal lecture] in the Dharma hall to inspire the monks to rise up, filled with the doctrine of the school's traditions. On those days of the month ending in a three or an eight, there is chanting to repay the dragons and the heavenly beings. The monks invite the abbot to give instruction on the profound teachings and to explain the links between the present and the past. ${ }^{59}$

Here, and in the more elaborate schedules provided by Keizan Jōkin in the $14^{\text {th }}$ century for monthly and daily recurring activities in the monastery, the form is still that of a list. ${ }^{60}$ Modern societies developed timetables and schedules, documents combining iconic and graphic elements to facilitate an overview of the duration, timing, sequence and tempo of actions to be performed and tasks to be implemented. ${ }^{61}$ The Brunswick railway timetable of 1890 [image 1, see next page] is a fine example in this regard, as it not only includes departure times, but also the durations of travel, and thus allows to glimpse tempo along with timing, duration, and sequence.

58 Beginning with the first of the month, i. e. on the $1^{\text {st }}, 5^{\text {th }}, 10^{\text {th }}, 15^{\text {th }}, 20^{\text {th }}$ and $25^{\text {th }}$. Compare Yifa and Zongze, The Origins of Buddhist Monastic Codes in China, 266-67. and the chapter on monthly scheduled events in Keizan's book of hours, Ichimura, Zen Master Keizan's Monastic Regulations, $33-68$.

59 Yifa and Zongze, The Origins of Buddhist Monastic Codes in China, 138.

60 Keizan, Jōsai Daishi zenshū, 260-72.

61 Zerubavel, "Timetables and Scheduling," 89-90. 
Image 1: The Brunswick and Western Railroad Timetable, 1890

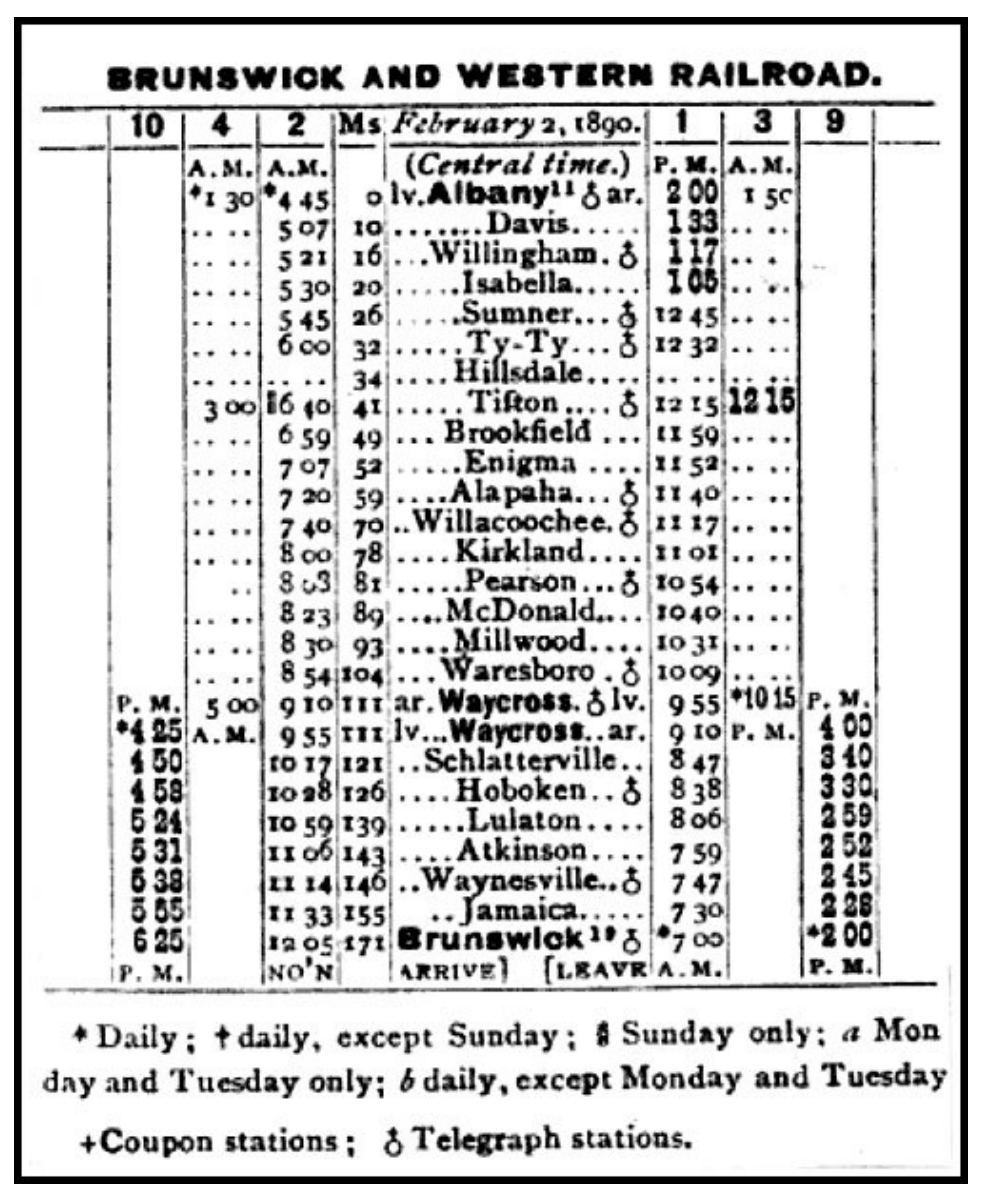

That, however, does not mean that practical chronography of necessity prefers formal chronometric determination. In many instances, injunctions are chronotypological in character. The locus classicus in the Judaeo-Christian tradition is of course Kohelet (Ecclesiastes), chapter 2, 1-8:

Everything has an appointed season, and there is a time for every matter under the heaven. A time to give birth and a time to die; a time to plant and a time to uproot that which is planted. A time to kill and a time to heal; a time to break and a time to build. A time to weep and a time to laugh; a time of wailing and a time of dancing. A time to cast stones and a time to gather stones; a time to 
embrace and a time to refrain from embracing. A time to seek and a time to lose; a time to keep and a time to cast away. A time to rend and a time to sew; a time to be silent and a time to speak. A time to love and a time to hate; a time for war and a time for peace.

The Japanese medical classic Ishinpō, a $10^{\text {th }}$ century commented compilation of Chinese sources on all aspects of medicine, provides many examples for the reasoning behind such thought. Consider the following passage on the appropriate time for sleep, which combines quantitative and attributive characterisation:

$$
\begin{aligned}
& \text { 臥セント欲スルニ、人定ノ時ヨ以ヒテシ、亥ヨ加フル无カレ。是ノ時天地人ノ万物皆臥シ } \\
& \text { テータビ死 } ヨ \text { 為シ、鬼路二 通ズ。 }{ }^{62}
\end{aligned}
$$

When wanting to lie down and sleep, keep the established hours, and do not stay awake into the hour of the boar [9-11 p.m.]. At this time, all things of heaven, earth, and the human realm lie down and die once, commuting to the realm of ghosts.

The above quotes might be taken to indicate that typological prescriptive chronography is a feature of wisdom literature, and obsolete in modern scientific writing. This is not correct. For example, a recent study concerning the timing of medication aimed at countering high blood pressure resumes pertinent facts in a typological manner:

Most importantly, the pharmacodynamic characteristics of most hypertension medications have been shown to be highly dependent on treatment-time. ${ }^{63}$

Here, time is specified by an attribute (treatment), and further identified as a relevant factor influencing the effect of the treatment. It is thus determined as part of a causal relationship. The study concludes in a similar vein:

The MAPEC study documents, for the first time, that a bedtime schedule with $\geq 1$ hypertension medications, in comparison to a schedule in which all such

62 Tanba, Ishinpō (maki 27) yōjō hen 医心方〈巻 27〉 養生篇, 167.

63 Hermida et al., "Influence of Circadian Time of Hypertension Treatment on Cardiovascular Risk." 
medications are ingested upon awakening, not only significantly and costeffectively improves $\mathrm{B}[$ lood] $\mathrm{P}[$ ressure] control and decreases the prevalence of non-dipping, but that it significantly reduces CVD [cardiovascular disease] risk. $^{64}$

In terms of chronothetic determination, such medical council is implicitly affirmative, as would be any form scheduling or prescriptive localization. Alternatively both may be conjoined with chronothetic negation, as in the parental injunction from Cat Stevens' famous song "Father and Son": "It's not time to make a change, just relax, take it easy, you're still young, that's your fault, there's so much you have to learn. ${ }^{65}$ ", Such negation may also be general, exemplified by Winston Churchill's famous speech at Harrow School: "Never give in. Never give in. Never, never, never - in nothing, great or small, large or petty - never give in, except to convictions of honour and good sense. Never yield to force; never yield to the apparently overwhelming might of the enemy." ${ }^{" 66}$ The one chronothetic function not applicable in practical chronography is that of limitation, as actions cannot happen outside of time.

Generalized chronographic assertions or negations appear to be conjoined with apodictic modality: What shall always or never happen is something that is prescribed or prohibited by some sort of necessity - logical, moral, or by way of causal connection; however, as in Churchill, the necessity may remain implicit in the generalized temporal marker. It needs explicit expression, however, when linked to an individual event or action: "I must be gone", says Romeo, "and live, or stay, and die." 67 Strength of conviction may also be rhetorically expressed by simple assertion. To quote another political speech, this time by Subcomandante Marcos: "It is time that

64 Hermida et al.

65 Stevens, Father and Son.

66 Gilbert, Churchill: The Power of Words. His Remarkable Life Recounted through His Writings and Speeches, 288.

67 "Romeo and Juliet", Act III, scene V. Cf. Shakespeare, The Complete Works of William Shakespeare, 973. 
this country stop being a shame clothed only in the color of money." ${ }^{68}$ On the other end of the spectrum, there are counterfactual hypothetic statements, such as Basil Hallward's words of regret to Lord Henry in The Picture of Dorian Gray: "You should have gone away when I asked you[.]"69

\section{Chronoaesthetics}

Insofar as the statements quoted in the last paragraph express feelings of urgency or regret, they also exemplify the third dimension of chronography to be discussed here, the dimension of attitudes toward time. More often than not, it will be described implicitly, as was the case in said quotations. Modal determinations often come with such connotations of attitude, but there are also many verbs engendering a certain disposition towards time. If "regret" is about a past that one wishes to have been different, "hope" is about the future. In both cases, it is a certain property or attribute of the time in question that the attitude relates to, and the same holds for expressions of "waiting", which depreciate a present state of affairs in relation to a future one, as evident in the famous waiting poem by Sosei Hōshi ${ }^{70}$ :

\begin{tabular}{|l|l|l|}
\hline 今こむと & Ima komu to & "I'll come right away!" \\
\hline いひしばかりに & ihishi bakari ni & Only because you said this \\
\hline 長月の & nagatsuki no & the long autumn night \\
\hline
\end{tabular}

68 Subcomandante Insurgente Marcos, "Marcos, Subcomandante Insurgente. Speech By Subcomandante Marcos, Ezln March 11. (2001)," https://documents.tips/download/link/marcossubcomandante-insurgente-speech-by-subcomandante-marcos-ezln-march-11-2001.html.

69 Oscar Wilde, 92.

70 Shinpen Kokka Taikan Henshū Iinkai, Shinpen kokka taikan, 5:933. Cf. Mostow, Pictures of the Heart, 204. I have followed the Kokinshū interpretation and changed the word/line order of the translation to fit more closely with the Japanese original. See also Honda, One Hundred Poems from One Hundred Poets, 21. 


\begin{tabular}{|l|l|l|}
\hline ありあけの月を & ariake no tsuki o & until the wan moon rose \\
\hline まちいでつるかな & machiideturu kana & have I ended up waiting \\
\hline
\end{tabular}

A more outspoken variant of such aesthetic typological chronography are Karl's initial words in Schiller's Die Räuber (Act I, Scene 2): "Mir ekelt vor diesem tintenklecksenden Säkulum [... $]^{71}$ (I am disgusted with this age of puny scribblers $\left.{ }^{72}\right) . "$ But aesthetic determination is not confined to the realm of subjective evaluation. This is demonstrated by the old legal principle periculum in mora ("danger in delay"), which justifies a change of procedure in cases of urgency. ${ }^{73}$ Here, as in Sosei Hōshi's poem, the typological is tied to the metric, since "delay" implies an evaluation of duration and tempo of events in relation to action. Similarly, expressions of boredom, anticipation and so forth imply an attitude towards the quantitative, metric aspects of time. It is therefore safe to say that basic functions of determination explicated under the heading of theoretic chronography (metric, typological, thetic, and modal) are also relevant to the dimension of the aesthetic.

\section{Conclusion}

The following poem by the $12^{\text {th }}$ century courtier Fujiwara no Kiyosuke may serve to sum up and conclude our analysis. ${ }^{74}$ It combines theoretical and aesthetic chronography to express the interdependence of time's aesthetic and quantitative $\operatorname{aspects}^{75}$ :

ながらえば

Nagaraeba If it be long enough

71 Schiller, Die Räuber: Ein Schauspiel, 21.

72 Schiller, "The Robbers," 15.

73 Patzschenski, Periculum in mora. I am indebted here to a yet unpublished presentation by Andreas Thier, given at the ISST conference "Time's Urgency" in Edinburgh, 2016.

74 Number 84 of the "Hundred poems of hundred poets" collection, see Honda, One Hundred Poems from One Hundred Poets, 84.

75 Shinpen Kokka Taikan Henshū Iinkai, Shinpen kokka taikan, 5:934. 
またこの此や

しのばれん

うしと見し世ぞ

今は恋しき mata kono koro ya

shinobaren

ushi to mishi yo zo

ima wa koishiki again for this moment

shall I come to pine?

The time that I considered sad

now it is dear to me.

The poem also exhibits modal determinations of attitude in contrasting the hypothetical form shinobaremu ("shall I pine?"), which points to an envisioned future change of attitude towards the present) with the assertive forms of mishi ("I considered") and koishiki ("is dear"), which describe factual attitudes of the past and present. In all its brevity, the poem therefore provides additional evidence that the functions of chronographic determination discussed here are by no means mutually exclusive. To the contrary, they complement each other. It is not, however, necessary that all functions are employed in a given text in order for its chronography to be well-developed. The above poem is certainly not chronographically deficient for its lack of fully relational metric determination. Generally speaking, different chronographic signatures are required depending on genre conventions and the specific communicative intent of a given text. Conversely, only a chronographic analysis that takes account of all the options and functions of determining time may serve to correctly identify the temporal perspective of a document. Exclusive emphasis on the quantitative aspects of chronography risks to loose sight of the abundance of other forms and dimensions of determination, and to misidentify deficiencies where there are none.

\section{References cited}

Abu-'r-Raiḥān Muḥammad Ibn-Aḥmad al- Bīrūnī, and Eduard Sachau. The Chronology of Ancient Nations: An English Version of the Arabic Text of the Athâr-Ul-BâKiya of Albîrunî, or, "Vestiges of the Past", Collected and Reduced to Writing by the Author in A.H. 390-391, A.D. 1000. London: London, 1879. 
Anderson, J. D., G. Schubert, V. Trimble, and M. R. Feldman. "Measurements of Newton's Gravitational Constant and the Length of Day." EPL (Europhysics Letters) 110, no. 1 (2015): 10002.

Brown, Delmer M, and Ichirō Ishida, eds. The Future and the Past: A Translation and Study of the Gukanshō. Berkeley: University of California press, 1979.

Cassirer, Ernst. Philosophie der symbolischen Formen II. 10th ed. Vol. 2: Das mythische Denken. Darmstadt: Wissenschaftliche Buchgesellschaft, 1994.

Changlu Zongze 長蘆宗賾. “Chanyuan Qinggui 禪苑清規” In Manji Zokuzō Kyō 民 續藏經 no.1245, 63:522ff. Tōkyō: Shin bunhō shuppan, 1994.

Dickinson, Emily. Poems. New York: Alfred A. Knopf : Distributed by Random House, Inc., 1993.

Dux, Günter. Die Zeit in der Geschichte: Ihre Entwicklungslogik vom Mythos zur Weltzeit : Mit kulturvergleichenden Untersuchungen in Brasilien (J. Mensing), Indien (G. Dux/K. Kälbe/J. Messmer) und Deutschland (B. Kiesel). Frankfurt am Main: Suhrkamp, 1989.

Eckhart, Master. "Prologues to the Opus Tripartitum." In Parisian Questions and Prologues. Translated by Armand Maurer, 77-104. Toronto, Canada: Pontificial Institute of Mediaeval Studies, 1974.

Eckhart, Meister. "Expositio Libri Genesi." In Die deutschen und lateinischen Werke, edited by Josef Quint, Georg Steer, Josef Koch, Heribert Fischer, Konrad Weiss, and Loris Sturlese, 1:185-233. Stuttgart: Kohlhammer, 1936. . "Expositio Libri Genesi." In The Essential Sermons, Commentaries, Treatises and Defense, edited by Bernard McGinn and Edmund Colledge, 82121. New York: Paulist Press, 1981.

. "Prologus Generalis in Opus Tripartitum." In Die deutschen und lateinischen Werke, edited by Josef Quint, Georg Steer, Josef Koch, Heribert Fischer, Konrad Weiss, and Loris Sturlese, 1:148-65. Stuttgart: Kohlhammer, 1936.

Garber, Joseph. Vertical Run. New York: Bantam, 1995. http://www.myilibrary.com? $\mathrm{id}=435429$.

Genette, Gérard. Figures III. Paris: Editions du Seuil, 1972.

Gilbert, Martin. Churchill: The Power of Words. His Remarkable Life Recounted through His Writings and Speeches. Boston: Da Capo Press, 2012.

Harweg, Roland. Zeit in Mythos und Geschichte. 1., Aufl. Lit Verlag, 2009. 
Heine, Heinrich. "Buch Der Lieder-Lyrisches Intermezzo." In Heinrich Heine: Sämtliche Werke in vier Bänden. Band I: Gedichte, 7th ed., 1-180. Düsseldorf; Zürich: Artemis \& Winkler, $199 \%$.

Heine, Heinrich, and Hal Draper. "Book of Songs-Lyrical Intermezzo." In The Complete Poems of Heinrich Heine: A Modern English Version by Hal Draper, 3-158. Oxford: Oxford University Press, 1982.

Heine, Steven. The Zen Poetry of Dōgen: Verses from the Mountain of Eternal Peace. Boston, MA: Tuttle Publishing, 1997.

Hermida, Ramón C., Diana E., Ayala, Artemio, Mojón, and José R., Fernández. "Influence of Circadian Time of Hypertension Treatment on Cardiovascular Risk: Results of the Mapec Study." Chronobiology International 27, no. 8 (October 1, 2010): 1629-51. https://doi.org/10.3109/07420528.2010.510230.

Honda, Heihachirō. One Hundred Poems from One Hundred Poets: Being a Translation of the Ogura Hyaku-Nin-Isshiu. Tokyo: The Hokuseido Press, 1993.

Ichimura Shōhei 市村昭平. Zen Master Keizan's Monastic Regulations $=$ 瑩山禅師(和 尚)清規. Daihonzan Sōjiji , North American Institute of Zen and Buddhist Studies, 1994.

Inoue Mitsusada 井上光貞. Ritsuryō 律令. Vol. 3. Nihon shisō taikei 日本思想体系. Tōkyō: Iwanami shoten, 1976.

Jandl, Ernst. Selbstporträt des Schachspielers als trinkende Uhr: Gedichte. Darmstadt: Luchterhand, 1983.

Kant, Immanuel. Kritik der reinen Vernunft. Edited by Jens Timmermann. Philosophische Bibliothek 505. Hamburg: Meiner, 1998.

Keizan 瑩山. Jōsai Daishi zenshū 常濟大師全集. Edited by Kohō Chisan 孤峰智璨. 2nd ed. Kanagawa: Daihonzan Sōjiji, $196 \%$.

Kitabatake, Chikafusa. A Chronicle of Gods and Sovereignns: Jinnō Shōtōki. Translated by H. Paul Varley. New York: Columbia University press, 1980.

Kitabatake Chikafusa 北畠 親房, Iwasa Masashi 岩佐正, and Tokieda Motoki 時枝誠 記. Jinnō shōtōki. Masukagami 神皇正統記 . 増鏡. Vol. 8\%. Nihon koten bungaku taikei. Tōkyō: Iwanami shoten, 1965.

Kojima Noriyuki 小島 憲之. Nihon shoki 日本書紀: 3. Nihon koten bungaku zenshū 日本古典文学全集 4. Tōkyō: Shōgakukan, 1998.

Marx, Karl. "Chapter Thirty Two-Historical Tendency of Capitalist Accumulation." In Capital: A Critique of Political Economy, edited by Frederick Engels, 
translated from the third german edition by Samuel Moore and Edward Aveling, 834-837. New York: Charles H. Kerr \& Company, 1906.

McTaggart, J. Ellis. "The Unreality of Time." Mind 17, no. 68 (1908): 457-74.

Mostow, Joshua S. Pictures of the Heart: The Hyakunin Isshu in Word and Image.

University of Hawaii Press, 1996.

Nakano Shigeharu 中野重治. Nakano Shigeharu shishū 中野重治詩集. Tōkyō:

Shichōsha, 1988.

Okami Masao 岡見 正雄 and Akamatsu Toshihide 赤松俊秀, eds. Gukansho 愚管抄.

Nihon Koten Bungaku Taikei 日本古典文學大系 86. Tōkyō: Iwanami shoten, $196 \%$.

Ōkubo Dōshu 大久保道舟, ed. Dōgen Zenji Zenshū 道元禅師全集. Tōkyō: Chikuma Shobō, 1969.

Oscar Wilde: Plays, Prose, Writings and Poems. London: J.M. Dent, 1975.

Patzschenski, Carolus Henricus. Periculum in mora. Wittenberg: Hake, 1743.

Publius Ovidius. The Metamorphoses of Ovid. Translated by Michael Simpson.

Amherst: University of Massachusetts Press, 2001.

Publius Ovidius Naso, ca v43-18, and Michael von Albrecht. Metamorphosen:

Lateinisch/Deutsch. Nachdruck der bibliogr. ergänzten Ausg. Vol. Nr. 1360.

Reclams Universal-Bibliothek. Stuttgart: Philipp Reclam, $200 \%$.

Schiller, Friedrich. Die Räuber: Ein Schauspiel. Mit Anmerkungen von Christian

Grawe. Vol. Nr. 15. Reclam Universal-Bibliothek. Stuttgart: Philipp Reclam, 2017.

—_. "The Robbers." In Friedrich Schiller's Works: The Robbers, Fiesco, Love and Intrigue, edited by John C. Nimmo, With five illustrations., 1-163.

London: John C. Nimmo, Ltd., 1903.

Shakespeare, William. The Complete Works of William Shakespeare. Reprint.

Glasgow: Harper Collins, 1994.

Shinpen Kokka Taikan Henshū Iinkai 新編国歌大観編集委員会, eds. Shinpen kokka taikan 新編国歌大観. Vol. 5. Shinpen kokka taikan. Tōkyō: Kadokawa shoten, 1987.

Spinoza, Benedict. Ethics by Benedict de Spinoza. Edited by Thomas Deegan and James Hogg. Translated by George Eliot. Salzburg Studies in English Literature under the Direction of Professor Erwin A. Stürzl. Romantic Reassessment. Salzburg: Institut für Anglistik und Amerikanistik, Universität Salzburg, 1981. 
Spinoza, Benedictus de. Ethik in geometrischer Ordnung dargestellt : LateinischDeutsch. Edited by Wolfgang Bartuschat. Philosophische Biobliothek 92. Hamburg: Meiner, 1999.

Steineck, Raji C. "Time in Old Japan: In Search of a Paradigm.” KronoScope 17, no. 1 (March 28, 2017): 16-36.

Stevens, Cat. Father and Son. 1970. LP Record "Tea for the Tillerman."

Subcomandante Insurgente Marcos. "Marcos, Subcomandante Insurgente. Speech By Subcomandante Marcos, Ezln March 11. (2001).” documents.tips, 2001. https://documents.tips/download/link/marcos-subcomandante-insurgentespeech-by-subcomandante-marcos-ezln-march-11-2001.html. Accessed March 15, 2018.

Swift, Jonathan, and Laurence Sterne. Guliver's Travels. Tristram Shandy. Chicago : Encyclopædia Britannica, 1952.

Tanba Yasuyori 丹波康頼. Ishinpō (maki 27) yōjō hen 医心方〈巻 27〉養生篇.

Translated by Maki Sachiko 槙佐知子. Tōkyō: Chikuma shobō, 1993.

Tawara Machi 俵万智. Sarada kinenbi サラダ記念曰. Tōkyō: Kawade shobō shinsha, 1990.

Unschuld, Paul. Medicine in China : A History of Ideas. Berkeley: University of California Press, 1985.

Yifa, and Zongze. The Origins of Buddhist Monastic Codes in China: An Annotated Translation and Study of the Chanyuan Qinggui. Classics in East Asian Buddhism. Honolulu: University of Hawaii Press, 2002.

Zanetti, Sandro. "Zeitoffen": zur Chronographie Paul Celans. [Zur Genealogie des Schreibens, 6]. Paderborn: Fink, 2006.

Zerubavel, Eviatar. Hidden Rhythms: Schedules and Calendars in Social Life. University of California Press, 1985.

- The Seven Day Circle: The History and Meaning of the Week. New York: The Free Press, 1985.

—. "Timetables and Scheduling: On the Social Organization of Time." Sociological Inquiry 46, no. 2 (1976): 87-94.

Image 1: The Brunswick and Western Railroad timetable, 1890 